\title{
Effectiveness of Mass Vaccination in Brazil against Severe COVID-19 Cases
}

Daniel A.M. Villela1, Tatiana Guimarães de Noronha, ${ }^{2,3}$, Leonardo S. Bastos ${ }^{1}$, Antonio G. Pacheco ${ }^{1}$, Oswaldo G Cruz ${ }^{1}$, Luiz Max Carvalho ${ }^{4}$, Claudia Torres Codeço ${ }^{1}$, Marcelo Ferreira da Costa Gomes ${ }^{1}$, Flávio Codeço Coelho ${ }^{4,5}$, Laís Picinini Freitas ${ }^{1}$, Raquel Martins Lana ${ }^{1}$, Victor Bertollo Gomes Porto ${ }^{6}$, Luiz Antônio Bastos Camacho ${ }^{7}$, Claudio José Struchiner ${ }^{4,8}$

1. Program of Scientific Computing, Fundação Oswaldo Cruz, Brazil

2. Institute of Technology for Immunobiologicals, Fundação Oswaldo Cruz, Brazil

3. School of Medicine, Universidade Federal Fluminense, Brazil

4. School of Applied Mathematics - Fundação Getúlio Vargas, Brazil

5. Institute of Global Health - University of Geneva, Switzerland.

6. National Immunization Program, Ministry of Health, Brazil

7. National School of Public Health, Fundação Oswaldo Cruz, Brazil

8. Institute of Social Medicine, Universidade do Estado do Rio de Janeiro, Brazil

*Corresponding author: daniel.villela@fiocruz.br

\begin{abstract}
Background. Mass vaccination campaigns started in Brazil on January/2021 with CoronaVac followed by ChAdOx1 nCov-19, and BNT162b2 mRNA vaccines. Target populations initially included vulnerable groups such as people older than 80 years, with comorbidities, of indigenous origin, and healthcare workers. Younger age groups were gradually included.
\end{abstract}

Methods. A national cohort of 66.3 million records was compiled by linking registry-certified COVID-19 vaccination records from the Brazilian National Immunization Program with information on severe COVID-19 cases and deaths. Cases and deaths were aggregated by state and age group. Mixed-effects Poisson models were used to estimate the rate of severe cases and deaths among vaccinated and unvaccinated individuals, and the corresponding estimates of vaccine effectiveness by vaccine platform and age group. The study period is from mid-January to mid-July 2021.

Results. Estimates of vaccine effectiveness preventing deaths were highest at $97.9 \%$ (95\% Crl: 93.5-99.8) among 20-39 years old with ChAdOx1 nCov-19, at 82.7\% (95\% Crl: 80.7-84.6) among 40-59 years old with CoronaVac, and at 89.9\% (87.8--91.8) among 40-59 years old with partial immunization of BNT162b2. For all vaccines combined in the full regimen, the effectiveness preventing severe cases among individuals aged $80+$ years old was 35.9\% (95\% 
Crl: 34.9-36.9) which is lower than that observed for individuals aged $60-79$ years $(61.0 \%, 95 \%$ Crl: 60.5-61.5).

Conclusion. Despite varying effectiveness estimates, Brazil's population benefited from vaccination in preventing severe COVID-19 outcomes. Results, however, suggest significant vaccine-specific reductions in effectiveness by age, given by differences between age groups 60-79 years and over 80 years.

\section{Introduction}

Brazil started its national COVID-19 vaccination campaign on January 17, 2021, right after exceeding 200,000 confirmed deaths. Since early in the COVID-19 pandemic, higher risks for severe COVID-19 disease and deaths were strongly related to age factors, pointed out by ageskewed distribution of cases and comorbidities $(1,2)$. Due to limitations in vaccine supplies during the first months of the campaign, a prioritization schedule was developed based on these risk evaluations by technical discussions at the National Immunization Program and the WHO SAGE recommendations (3). Priority was given to those at higher risk of severe disease (elderly, chronic health conditions, and disabled population), vulnerable populations, health care workers, and lastly, essential workers. After completion of the aforementioned groups, vaccination was extended to the entire population in sequential order given by decreasing age.

The nationwide vaccination campaign started with two main vaccines, CoronaVac (SinoVac) and ChAdOx1 nCov-19 (AstraZeneca/Oxford University), initially imported to cover demands, and later produced by Instituto Butantan, São Paulo, and Fundação Oswaldo Cruz, Rio de Janeiro, respectively. Full-regimen vaccination (two doses) was completed after a 28-day (CoronaVac) or 12-week (ChAdOx1 nCov-19) recommended intervals. This time difference made the initial vaccinated groups complete the full regimen as early as February (CoronaVac) or mid-April (ChAdOx1 nCov-19). The campaign policy was to provide vaccination doses over time to the states following a distribution proportional to the states' populations. On April 29, BNT162b2 mRNA vaccine (Pfizer-BioNTech) was integrated into the regular immunization distribution. Later, on June 15, Ad26.COV2.S vaccines (Janssen) were also imported and integrated into the national immunization program. Brazil adopted a 12-week interval for the BNT162b2 vaccines, whereas Ad26.COV2.S required a single dose. COVID-19 vaccine doses have been administered solely by the public health system and recorded in an electronic database managed by the Ministry of Health. 
As Brazil started to implement the vaccination in January 2021, the gamma variant of concern (VOC) was already present in a few states, appearing first in the North and quickly disseminating in the country (4). A mix of factors including the emergence of the new variant, a slow pace in advancing vaccination coverage, and easing or absence of restrictions in many cities and states led to another escalation in the number of cases and, consequently, hospitalizations and deaths. Subsequently, the number of reported cases started decreasing nationwide, even though the epidemiological scenario varied across several states.

Here we report on a massive data analysis to assess the Brazilian vaccination program effectiveness over the initial six months, based on a cohort of health records derived from linkage of two national databases: (1) records of vaccination events and (2) severe COVID-19 cases, including deaths. Therefore, an evaluation of the vaccination program as a whole was possible, as well as separate analyzes investigating the rates of hospitalization and deaths among vaccinated individuals vaccinated with ChAdOx1 nCov-19, CoronaVac, and BNT162b2 mRNA vaccines. The statistical analysis involved a mixed-effects model to estimate the rate ratios between vaccinated and unvaccinated individuals in multiple combinations of outcomes, vaccination regimen, and vaccine, adjusting for age groups and state of residency. The evidences from this work were presented to the technical committee for immunization in the Ministry of Health overseeing the COVID-19 vaccination campaign.

\section{Methods}

\section{Study population}

The National Immunization Program (NIP) provided an anonymized dataset containing individual-level data on vaccination and the occurrence of Severe Acute Respiratory IIIness (SARI). The dataset was constructed by the NIP through probabilistic linkage of vaccination data registered at the National Network of Health Data (RNDS) and the data related to SARI cases from the Influenza Epidemiological Surveillance System (SIVEP-Gripe), which include hospitalized cases and deaths (details in Supplementary Text). SARI patient's nasopharyngeal samples are routinely screened for virus detection. Since the emergence of SARS-CoV-2 virus in Brazil in 2020, SARI cases have occurred predominantly due to SARS-CoV-2 infections, accounting for over $98 \%$ of the laboratory-confirmed cases of SARI. Cases with a diagnosis of infection by other viruses were excluded. Records with different vaccines in the first and second doses were disregarded, as well as those with absence of first dose information (date or vaccine manufacturer) but with second dose information. The exploratory analysis included all ages. 
The statistical analysis included only individuals over 20 years of age. The vaccination database included data up to June 30, 2021, whereas data from SIVEP had notifications as late as July 18, 2021.

Population data by age groups and states were extracted from a national projection maintained by the Brazilian Ministry of Health (source: DataSUS).

\section{Immunization status}

The COVID-19 vaccination campaign started on January 17,2021 , the first epoch for the study (T0). Effectiveness was evaluated in groups either partially or fully immunized ( $\geq 14$ days after the first dose) and fully immunized ( $\geq 14$ days after the second dose). Effectiveness were considered in the overall vaccination program (all vaccines) as well as vaccine-specific, CoronaVac, ChAdOx1 nCov-19, and BNT162b2. ChAdOx1 nCov-19 (AZD1222), by Oxford/AstraZeneca, was first imported as Covishield and later produced as Vaxzevria. Vaccination effectiveness for BNT162b2 after two-dose regimen were not evaluated due to short time for observing outcomes in the study period. Vaccination with Janssen started later and, by the last day of observation in the cohort, there were significantly fewer individuals and most importantly, very little time to observe the outcomes of interest. The population data permitted an estimation of the unvaccinated population by age group and states

\section{Case definition - outcomes of interest}

Outcomes of interest were serious illness, i.e. confirmed and probable COVID-19 cases with symptoms leading to hospitalization and COVID-19-related deaths, independent of prior hospitalization. The former could also include death subsequently. The outcomes are signaled in the database by the date of symptoms onset and the final case status (death, recovered or ignored). For each person in the cohort, an outcome of serious COVID-19 illness occurred whenever this person was notified as a COVID-19 SARI case in the national database, using the date of symptoms onset as reference. Therefore, a severe COVID-19 illness after immunization, either partially or fully, characterized an immunized case. Cases without a registry of vaccination or with symptoms before vaccination status were classified as unvaccinated cases. For the outcome of death-only, individuals were counted, if death was registered in the electronic record, and their vaccination status was also dependent on the date of immunization and date of symptoms onset. Vaccinated individuals without any registry of 
medRxiv preprint doi: https://doi.org/10.1101/2021.09.10.21263084; this version posted September 15, 2021. The copyright holder for this preprint (which was not certified by peer review) is the author/funder, who has granted medRxiv a license to display the preprint in perpetuity.

It is made available under a CC-BY-NC-ND 4.0 International license .

severe COVID-19 during the study period were considered as not presenting the outcomes of interest.

\section{Statistical analysis}

Cases of severe COVID-19 were aggregated by age group (20 - 39, 40 - 59, 60 - 79, and 80+ years old), vaccination status (immunized/not immunized), and the states of residency. The analysis involved a mixed-effects Poisson model to evaluate the case rate ratios (RR), and estimates of vaccination effectiveness 1-RR, which were evaluated per age-group, or per targeted population. We also evaluated overall and vaccine-specific effectiveness. The same framework applies for evaluating effectiveness in preventing deaths. Details about the model are given in the Supplementary Text. 
medRxiv preprint doi: https://doi.org/10.1101/2021.09.10.21263084; this version posted September 15, 2021. The copyright holder for this preprint (which was not certified by peer review) is the author/funder, who has granted medRxiv a license to display the preprint in perpetuity.

It is made available under a CC-BY-NC-ND 4.0 International license .

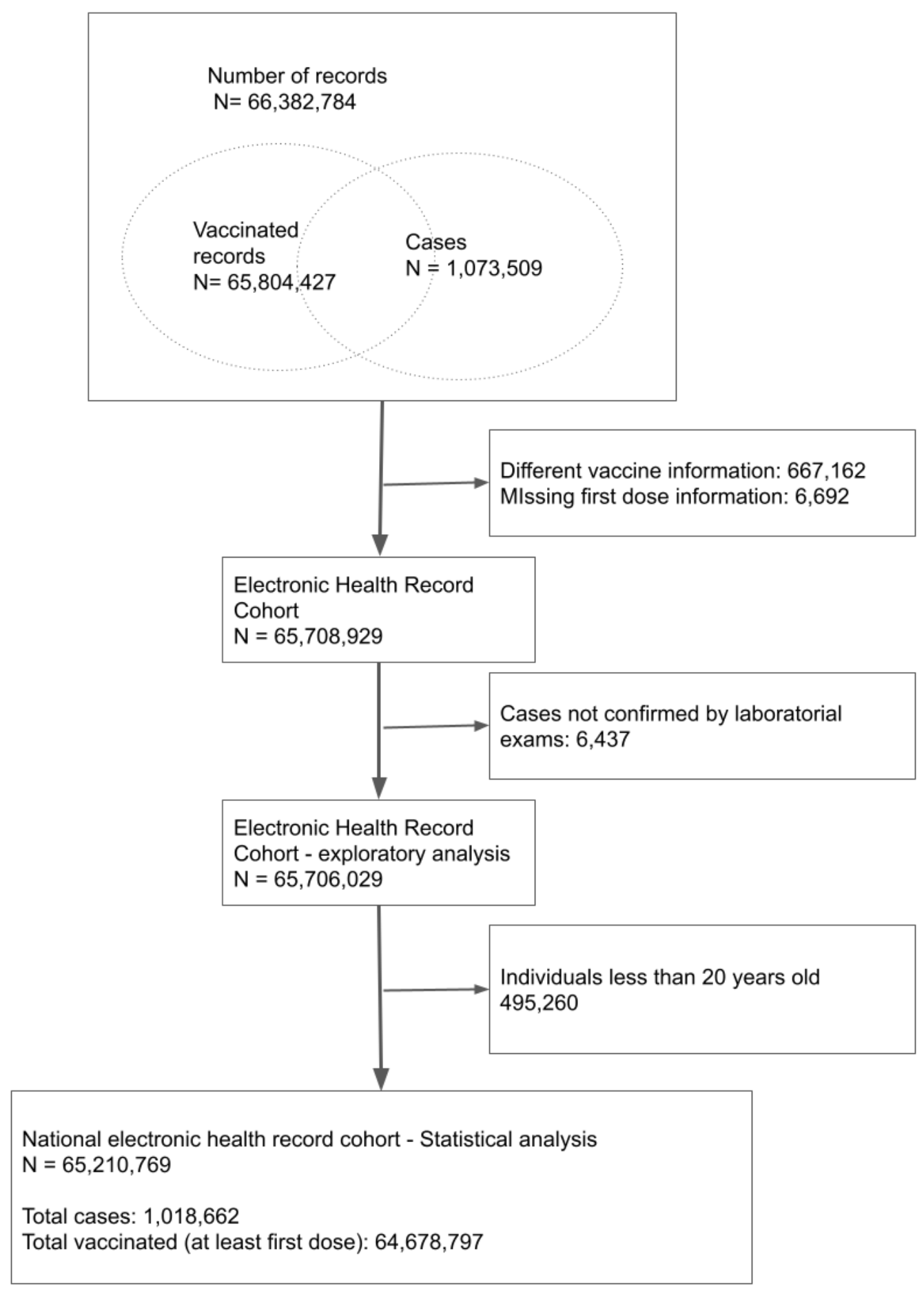

Figure 1: The electronic health record cohort and the databases for exploratory and statistical analysis. The cohort includes both cases from the Brazilian surveillance system (SIVEP-gripe) and the national vaccination databases. After exclusion criteria, there were $784,943(77 \%)$ confirmed cases, and 233,719 (23\%) probable cases. 


\section{Results}

In the first six months, the majority of first doses (36.6 million) were ChAdOx1 nCov-19 vaccines, whereas most individuals completing full vaccination regimen received CoronaVac (17.3 million) (Table 1). Of individuals with CoronaVac complete regimen, most were in the age groups of $60-79(65.4 \%)$ and $80+$ years old (12.0\%). Conversely, most cases of fully-immunized individuals with BNT162b2 were in the $20-39$ and $40-59$ years old groups $(33.8 \%$ and $61.5 \%$, respectively). For ChAdOx1 nCov-19, the group of 40-59 years old more frequently received at least the first dose (52.5\%), whereas individuals fully vaccinated were more concentrated in the age groups of $60-79(30.4 \%)$ and $80+$ years old (33.0\%). As expected, the Southeast region concentrated most vaccinated individuals due to population sizes, whereas North and CenterWest regions had proportionally fewer vaccinations.

Most cases of severe COVID-19 illness (Table 2) among individuals immunized with at least a first dose of ChAdOx1 nCov-19 vaccines were in the age groups of 60-79 and 80+ years old (40.7\% and $35.4 \%$, respectively). Of cases in fully immunized individuals with ChAdOx1 nCov$19,74.6 \%$ were $80+$ years or older. Most hospitalized cases among CoronaVac immunized individuals occurred in the age group of 60-79 years old, $59.5 \%$ of them with at least one dose and $53.7 \%$ with two doses. Hospitalized cases among BNT162b2-immunized (partially) individuals were concentrated in the age group of 40-59 years old. Deaths among fullyimmunized individuals were $80.5 \%$ (ChAdOx1 nCov-19 group) and exceeded $90 \%$ counting both groups 60-79 and 80+ receiving CoronaVac (Table 3).

The overall effectiveness of the vaccination program independent of the vaccine and age was $55.3 \%$ (54.9 - 55.7\%) preventing severe COVID-19 cases, considering the two-dose regimen. For ChAdOx1 nCov-19 and CoronaVac, effectiveness for severe cases was, respectively, 72.8\% (95\% Crl: 71.8 - 73.8\%) and 53.4\% (95\% Crl: 53.0\% - 53.8\%), on a two-dose regimen, independent of age. Effectiveness preventing severe cases with full immunization considering all vaccines exceeded $50 \%$ in age groups of 20-39, 40-59, 60-79 years old, preventing severe cases, and all age groups for death outcomes (Table 4). Effectiveness of ChAdOx1 nCov-19 was highest preventing severe cases among individuals 40-59 years old, reaching 90.4\% [95\% Credibility Interval (Crl): 88.7-92.0\%]. Effectiveness of CoronaVac was highest among individuals 40-59 years old reaching 71.0\% (95\% Crl: 69.8-72.1) for severe cases. Effectiveness of BNT162b2 with at least one dose in preventing severe cases was highest among individuals 40-59 years old, and 60-79 years old, reaching 81.2 (95\% Crl: 79.9--82.4) and $81.6 \%$ (95\% Crl: 
78.3--84.6), respectively, in these groups. Most importantly, the estimates for preventing severe cases in the group 60-79 years old at 79.6\% (95\% Crl: 77.8-81.3), for ChAdOx1 nCov-19, and 60.4 (95\% Crl: 59.9-60.9), for CoronaVac, decreased to $66.7 \%$ (95\%Crl: $65.1-68.1$ ) and 29.6\% (95\% Crl: 28.5-30.8), for ChAdOx1 nCov-19 and CoronaVac, respectively, with the group of 80+ years.

Vaccine effectiveness was higher when analyzing death outcomes for all three vaccines. For CoronaVac fully immunized individuals, effectiveness was highest at 82.7\% (95\% Crl: 80.7$84.6 \%$ ) in the group 40-59 years old. For full immunization with ChAdOx1 nCov-19 vaccine, the effectiveness preventing deaths was highest at 97.9\% (95\% Crl: 93.5--99.8) among 20-39 year old individuals and higher than $80 \%$ in all age groups. BNT162b2 effectiveness in the Brazilian population groups, which included partially immunized individuals, was highest in groups 40-59 and 60-79, respectively, estimated at 89.9\% (95\% Crl: 87.8--91.8) and 89.6 (95\% Crl: 85.1 -93.2) on preventing death. Effectiveness preventing deaths diminished with age, most significantly in the group of $80+$ years old.

The effectiveness estimates on full regimen in all Brazilian regions were higher in the group 6079 years old than those obtained in the group of $80+$, both for CoronaVac and ChAdOx1 nCov19, with severe cases and deaths as outcomes (Figure S2). The difference between effectiveness estimates in both groups is beyond the statistically significant bands for CoronaVac, except for severe cases in the North region. In the South and Southeast regions, the lowest estimates are below $50 \%$. The differences between the effectiveness of ChAdOx 1 nCov-19 vaccination in these groups were more significant in analyzing severe cases. Figure S3 shows the trends when considering the overall vaccination program.

Figure S4 shows how the incidence by age groups of severe COVID-19 cases peaked in March 2021 in macroregions of Brazil. Thereafter, incidences have declined in all age groups, most notably in 60-79. The 80+ year-old group, however, remained with the highest incidence, which plateaued in the Center-West, South, and Southeast regions. The great majority of sequenced COVID-19 cases from this study period in all regions were attributed to the gamma VOC (Figure S5). 


\section{Discussion}

The effectiveness of the Brazilian vaccination program against COVID-19, including the effectiveness of the deployed vaccines, ChAdOx1 nCov-19, CoronaVac, and BNT162b2, up to mid-July, varied considerably with age in this massive data analysis of severe COVID-19 cases and death as outcomes of interest. Results from this work were shared with the National Immunization Program and discussed within the National Advisory Committee on Immunization.

The effectiveness estimates reached high values for severe cases in most age groups, even higher figures preventing death outcomes and tight uncertainty intervals. In the group of nonelderly adults (20-39, 40-59), vaccine effectiveness for CoronaVac fully-vaccinated individuals went over $80 \%$ preventing death and over $70 \%$ preventing severe disease among 40-59 individuals. CoronaVac was the most frequent vaccine among fully-vaccinated individuals, hence putting the numbers of the overall vaccination program closer to the CoronaVac estimates. Effectiveness preventing severe disease was above $80 \%$ for the $20-39,40-59,60-79$ age groups, considering partially or fully vaccinated with BNT162b2. Effectiveness estimates in individuals receiving ChAdOx1 nCov-19 full immunization exceeded $80 \%$ for preventing severe disease in non-elderly groups, and $60 \%$ for the elderly groups, and were higher than $90 \%$ for preventing death in non-elderly and $80 \%$ in elderly groups.

Serious concerns remain due to the diminishing effectiveness observed as age increases, particularly differences between 60-79 and 80+ age groups. Immunosenescence, a potentially limited duration of immunity, and earlier immunization in the $80+$ group could also have led to lower effectiveness, given that this group had priority to start the immunization, in accordance with some studies $(5,6)$. The states in the South and Southeast regions are the most populated and concentrated most of this difference. Conversely, the states in the North region had less reduction. Some of these states already had a high circulation of the gamma variant when vaccination started, with a higher incidence of severe COVID-19 cases during the first months, whereas both an increase of severe COVID-19 incidence and gamma variant predominance were observed a few weeks later in the other regions (Figures 3 and S3).

ChAdOx1 nCov-19 and CoronaVac were the most used vaccines in the period since most records of first dose were from ChAdOx1 nCov-19 receivers, and most people completing the immunization regimen were CoronaVac receivers. In addition, the number of vaccinated records 
in the age groups 40-59, 60-79, and 80+ indicate a significant but increasing immunization coverage, whereas numbers were relatively lower in the group 20-39. Therefore, our analyses were more robust for the former age groups.

The vaccination program likely played a major role in reducing severe cases and deaths over the weeks, especially after April, when vaccination coverage scaled up in several age groups. Accordingly, an early assessment via a demographic approach by Victora et al. showed changing COVID-mortality trends in Brazil with the increase of vaccination rates in the country (7). In Figure 3, while incidence kept clearly decreasing among 60-79 year old individuals during the period of late March to July in all regions, in which full vaccination coverage for that group was increasing, for the mostly unvaccinated or partially vaccinated age groups 20-39 and 40-59 there was a clear rebound between late April and early July. For those younger adults, this rebound reached values as high as those observed in March. A similar trend happened initially for the age group 80+, although by late April, cases stopped decreasing and reached a plateau, probably a consequence of significant vaccination coverage, combined with a sustained viral transmission in the population. Despite the overall decrease in incidence, the incidence in the $80+$ year old group remained the highest, suggesting an effect of the lower vaccine's effectiveness in this age group.

The methodology here has advantages over the Screening method, described in WHO guidelines (8), due to the use of rate ratios and stratification by age groups and states, a sound approach given the variability of incidences across a large country such as Brazil. In addition, it is similar to evaluation methods of other vaccination programs such as Influenza (9).

Effectiveness estimates of ChAdOx1 nCov-19 in Brazil are compatible with prior findings on its efficacy and prior effectiveness. Results in blind, randomized, controlled trials of ChAdOx1 nCov-19 indicated the efficacy of $62 \%$ in individuals receiving two regular doses, and $90 \%$ with combination of low dose/regular dose, with overall efficacy assessed at $70.4 \%$ (54.8 - 80.6\%) (10), and subsequently assessed at 76.0\% (59.3-85.9) after a first single dose and $81.3 \%(95 \%$ $\mathrm{Cl} 60 \cdot 3-91 \cdot 2)(11)$. A test-negative case-control study to evaluate effectiveness of both BNT162b2 and ChAdOx1 nCov-19 found 73\% (27\% to 90\%) for ChAdOx1 nCov-19 with a further reduction of $37 \%$ risk of hospitalization (12). Here, the effectiveness of at-least partially immunized individuals also included fully immunized individuals, however, in the case of ChAdOx1 nCov-19, the majority was still in a single-dose. 
Efficacy of CoronaVac in a double-blind, randomized, controlled trial was estimated at $83.5 \%$ (65.4-92.1) after the second dose (13), whereas effectiveness in Chile indicated $87.5 \%(95 \%$ $\mathrm{Cl}, 86.7$ to 88.2$)$ for the prevention of hospitalization, and $86.3 \%(95 \% \mathrm{Cl}, 84.5$ to 87.9$)$ for the prevention of Covid-19-related death (14). The same study indicated effectiveness of CoronaVac full immunization over 60 years of age at $85.3 \%$ (84.3-86.3) for hospitalization and 86.5\% (84.6-88.1) for death. Thus, effectiveness in Brazil preventing severe cases was lower after a full CoronaVac regimen in the age groups 60-79 years old and over 80 years. Still, it was close to recent estimates of a test-negative case-control study that evaluated effectiveness over 70 years of age in São Paulo (15) and among healthcare workers in Manaus (16).

Efficacy of the BNT162b2 vaccine in randomized controlled trials was assessed at 95.0\% (90.097.9) (17). Effectiveness of BNT162b2 vaccination in Israel, evaluated in a case-control design, was at $87 \%$ (55-100\%) for hospitalized cases after seven days from regimen completion (18). Bernal et al. found the effectiveness of BNT162b2 was $61 \%(51-69 \%)$ for symptomatic cases in a test-negative case-control design with a further reduction of $43 \%$ risk of hospitalization (12). In our study, the effectiveness of BNT162b2 was in general below these levels, yet evaluation of the BNT162b2 vaccine was more limited due to the smaller number of immunized individuals and shorter follow up time, especially for the elderly.

The impact of VOCs on vaccine effectiveness is an evolving issue. Few studies have evaluated the impact on humoral immune responses, with a modest reduction of responses in either ChAdOx1 nCov-19 or BNT162b2 in the presence of the delta variant, although with a more significant difference with a single dose, i.e., before the second dose (19), and lower levels of neutralizing antibodies in healthcare workers with a two-dose regimen of CoronaVac in Thailand for the alpha, beta, and delta VOC, with a more pronounced reduction for the delta VOC (20). Shapiro et al. provide a comprehensive review on the effectiveness of COVID-19 vaccines (21). Our methodology can be used to monitor vaccine effectiveness over time and will be applied to monitor the potential impact of these VOCs on vaccine effectiveness in Brazil.

A few factors related to confounding effects and time-varying exposure to SARS-CoV-2 may hinder the effectiveness evaluation. The analysis is sensitive to COVID-19 incidence over time, the occurrence of VOCs, and other interventions during the study period, such as restrictive measures in some municipalities and/or states. The easing of non-pharmacological measures after vaccination, such as less frequent use of masks and increased face-to-face social interactions without proper distancing and ventilation care, can induce a greater risk of infection. 
Prevalences of comorbidities and exposure risk can be confounders, particularly in the young adults, among which individuals with comorbidities and healthcare workers were initially prioritized for vaccination, inducing a potential selection bias. Such bias is likely less significant for individuals over 60 years old since vaccination in this group was mainly targeted by age. Furthermore, the methodology depends on the quality of notifications of vaccinating records and cases in databases and on projections of the resident population by age group in the states, since the most recent census data in Brazil is from 2010. Still, the methodology can be adapted to changing epidemiological scenarios, and its use on permanent monitoring of the effectiveness should be pursued to investigate potential confounders further.

Finally, permanent efforts are necessary to estimate the vaccination effectiveness in the various epidemiological contexts of Brazil and other countries. Results from a timely evaluation of vaccination effectiveness can be updated periodically and integrate regular surveillance, hence they are instrumental to be shared with authorities, in this case, the Brazilian Ministry of Health. Furthermore, considering the biological plausibility of immunosenescence and the possibility of decreased immunity over time, especially in the context of VOC spreading, more studies with the elderly are needed towards potential revaccination to avoid serious COVID-19 illness and deaths.

\section{Acknowledgement}

Authors would like to thank GISAID for the access to the database of lineages of SARS-CoV-2 virus in Brazil and Ana Tereza R. de Vasconcelos and Luiz G. P. de Almeida for helping with obtaining the GISAID information from Brazil. The authors had support from INOVA Fiocruz, CAPES, CNPq (Refs. 441057/2020-9, 309569/2019-2). The Brazilian Ministry of Health supported the project and provided the anonymized database.

\section{Conflict of Interest}

Authors DAMV, CTC, MFCG, LSB, OGC, LPF, RML, AGFP, PML, TGN, LABC are affiliated with Fundação Oswaldo Cruz, a research institution in the Public Health Sciences, whose unit BioManguinhos has an agreement with AstraZeneca to produce ChAdOx1 nCov-19 vaccines. VBGP works for the National Immunization Program. 


\section{Data Statement}

Data in this study comes from a database maintained by the Brazilian Ministry of Health $(\mathrm{MoH})$, which provided the anonymized database for the analyses.

\section{Ethics Statement}

The study was conducted in accordance with fundamental ethical principles of the Declaration of Helsinki and the Brazilian National Health Council on research involving human beings. The study protocol was approved by the Research Ethics Committee of the Evandro Chagas National Institute of Infectious Diseases- Fiocruz (CAAE: 51567721.9.0000.5262).

\section{References}

1. Hawryluk I, Mellan TA, Hoeltgebaum H, Mishra S, Schnekenberg RP, Whittaker C, et al. Inference of COVID-19 epidemiological distributions from Brazilian hospital data. J R Soc Interface. 2020 Nov 25;17(172):20200596.

2. Ranzani OT, Bastos LSL, Gelli JGM, Marchesi JF, Baião F, Hamacher S, et al. Characterisation of the first 250000 hospital admissions for COVID-19 in Brazil: a retrospective analysis of nationwide data. Lancet Respir Med [Internet]. 2021 Jan 15 [cited 2021 Feb 9];0(0). Available from:

https://www.thelancet.com/journals/lanres/article/PIIS2213-2600(20)30560-9/abstract

3. World Health Organization W. WHO SAGE Roadmap For Prioritizing Uses Of COVID-19 Vaccines In The Context Of Limited Supply [Internet]. [cited 2021 Aug 28]. Available from: https://www.who.int/publications-detail-redirect/who-sage-roadmap-for-prioritizing-uses-ofcovid-19-vaccines-in-the-context-of-limited-supply

4. Faria NR, Mellan TA, Whittaker C, Claro IM, Candido D da S, Mishra S, et al. Genomics and epidemiology of the P.1 SARS-CoV-2 lineage in Manaus, Brazil. Science. 2021 May 21;372(6544):815-21.

5. Chen Y, Klein SL, Garibaldi BT, Li H, Wu C, Osevala NM, et al. Aging in COVID-19: Vulnerability, immunity and intervention. Ageing Res Rev. 2021 Jan;65:101205.

6. Khoury DS, Cromer D, Reynaldi A, Schlub TE, Wheatley AK, Juno JA, et al. Neutralizing antibody levels are highly predictive of immune protection from symptomatic SARS-CoV-2 infection. Nat Med. 2021 Jul;27(7):1205-11.

7. Victora PC, Castro PMC, Gurzenda S, Medeiros AC, França GVA, Barros PAJD. Estimating 
the early impact of vaccination against COVID-19 on deaths among elderly people in Brazil: Analyses of routinely-collected data on vaccine coverage and mortality. EClinicalMedicine [Internet]. 2021 Aug 1 [cited 2021 Aug 29];38. Available from: https://www.thelancet.com/journals/eclinm/article/PIIS2589-5370(21)00316-3/abstract

8. World Health Organization W. Evaluation of COVID-19 vaccine effectiveness [Internet]. [cited 2021 Aug 27]. Report No.: WHO/2019-

nCoV/vaccine_effectiveness/measurement/2021.1. Available from: https://www.who.int/publications-detail-redirect/WHO-2019-nCoV-vaccine_effectivenessmeasurement-2021.1

9. Baum U, Auranen K, Kulathinal S, Syrjänen R, Nohynek H, Jokinen J. Cohort study design for estimating the effectiveness of seasonal influenza vaccines in real time based on register data: The Finnish example. Scand J Public Health. 2020 May 1;48(3):316-22.

10. Voysey M, Clemens SAC, Madhi SA, Weckx LY, Folegatti PM, Aley PK, et al. Safety and efficacy of the ChAdOx1 nCoV-19 vaccine (AZD1222) against SARS-CoV-2: an interim analysis of four randomised controlled trials in Brazil, South Africa, and the UK. The Lancet. 2021 Jan 9;397(10269):99-111.

11. Voysey M, Clemens SAC, Madhi SA, Weckx LY, Folegatti PM, Aley PK, et al. Single-dose administration and the influence of the timing of the booster dose on immunogenicity and efficacy of ChAdOx1 nCoV-19 (AZD1222) vaccine: a pooled analysis of four randomised trials. The Lancet. 2021 Mar 6;397(10277):881-91.

12. Bernal JL, Andrews N, Gower C, Robertson C, Stowe J, Tessier E, et al. Effectiveness of the Pfizer-BioNTech and Oxford-AstraZeneca vaccines on covid-19 related symptoms, hospital admissions, and mortality in older adults in England: test negative case-control study. BMJ. 2021 May 13;373:n1088.

13. Tanriover MD, Doğanay HL, Akova M, Güner HR, Azap A, Akhan S, et al. Efficacy and safety of an inactivated whole-virion SARS-CoV-2 vaccine (CoronaVac): interim results of a double-blind, randomised, placebo-controlled, phase 3 trial in Turkey. The Lancet. 2021 Jul 17;398(10296):213-22.

14. Jara A, Undurraga EA, González C, Paredes F, Fontecilla T, Jara G, et al. Effectiveness of an Inactivated SARS-CoV-2 Vaccine in Chile. N Engl J Med. 2021 Jul 7;0(0):null.

15. Ranzani OT, Hitchings MDT, Dorion M, D’Agostini TL, de Paula RC, de Paula OFP, et al. Effectiveness of the CoronaVac vaccine in older adults during a gamma variant associated epidemic of covid-19 in Brazil: test negative case-control study. BMJ. 2021 Aug 20;374:n2015. 
16. Hitchings MDT, Ranzani OT, Torres MSS, Oliveira SB de, Almiron M, Said R, et al. Effectiveness of CoronaVac among healthcare workers in the setting of high SARS-CoV-2 Gamma variant transmission in Manaus, Brazil: A test-negative case-control study. Lancet Reg Health - Am [Internet]. 2021 Jul 25 [cited 2021 Aug 27];0(0). Available from: https://www.thelancet.com/journals/lanam/article/PIIS2667-193X(21)00017-X/abstract

17. Polack FP, Thomas SJ, Kitchin N, Absalon J, Gurtman A, Lockhart S, et al. Safety and Efficacy of the BNT162b2 mRNA Covid-19 Vaccine. N Engl J Med. 2020 Dec $31 ; 383(27): 2603-15$.

18. Dagan N, Barda N, Kepten E, Miron O, Perchik S, Katz MA, et al. BNT162b2 mRNA Covid19 Vaccine in a Nationwide Mass Vaccination Setting. N Engl J Med. 2021 Apr 15;384(15):1412-23.

19. Lopez Bernal J, Andrews N, Gower C, Gallagher E, Simmons R, Thelwall S, et al. Effectiveness of Covid-19 Vaccines against the B.1.617.2 (Delta) Variant. N Engl J Med. 2021 Aug 12;385(7):585-94.

20. Vacharathit V, Aiewsakun P, Manopwisedjaroen S, Srisaowakarn C, Laopanupong T, Ludowyke $\mathrm{N}$, et al. CoronaVac induces lower neutralising activity against variants of concern than natural infection. Lancet Infect Dis [Internet]. 2021 Aug 26 [cited 2021 Aug 27];0(0). Available from: https://www.thelancet.com/journals/laninf/article/PIIS14733099(21)00568-5/abstract

21. Shapiro J, Dean NE, Madewell ZJ, Yang Y, Halloran ME, Longini I. Efficacy Estimates for Various COVID-19 Vaccines: What we Know from the Literature and Reports [Internet]. 2021 Jun [cited 2021 Sep 1] p. 2021.05.20.21257461. Available from: https://www.medrxiv.org/content/10.1101/2021.05.20.21257461v2 
medRxiv preprint doi: https://doi.org/10.1101/2021.09.10.21263084; this version posted September 15, 2021. The copyright holder for this preprint (which was not certified by peer review) is the author/funder, who has granted medRxiv a license to display the preprint in perpetuity.

It is made available under a CC-BY-NC-ND 4.0 International license .

Tables

Table 1. Number of vaccinated individuals by vaccine and regimen (partial to full, and full) in Brazil from January 17 to June 30, 2021. Strata include age groups, sex, and the five regions of Brazil. Numbers for $1+$ dose present the number of individuals in the cohort that received at least the first dose, hence also counting the fully vaccinated individuals. Values in percentages indicate the proportions of each stratum item by the total in the stratum/vaccine/regimen.

\begin{tabular}{|c|c|c|c|c|c|c|c|}
\hline & & \multicolumn{2}{|c|}{ ChAdOx1 nCov-19 } & \multicolumn{2}{|l|}{ CoronaVac } & \multicolumn{2}{|l|}{ BNT162b2 } \\
\hline & & $1+$ dose $(\%)$ & $\begin{array}{l}\text { full regimen } \\
(\%)\end{array}$ & $1+$ dose $(\%)$ & $\begin{array}{l}\text { full regimen } \\
(\%)\end{array}$ & $1+$ dose $(\%)$ & $\begin{array}{l}\text { full } \\
\text { regimen } \\
(\%)\end{array}$ \\
\hline \multirow{5}{*}{$\begin{array}{l}\text { Age } \\
\text { group }\end{array}$} & $0-19$ & $285,064(0.8)$ & $15,160(0.5)$ & $86,507(0.4)$ & $53,959(0.3)$ & $86,244(1.3)$ & $458(1.2)$ \\
\hline & $20-39$ & $\begin{array}{l}6,775,915 \\
(18.5)\end{array}$ & $\begin{array}{l}586,273 \\
(18.8)\end{array}$ & $\begin{array}{l}2,643,137 \\
(12.3)\end{array}$ & $\begin{array}{l}1,995,119 \\
(11.5)\end{array}$ & $\begin{array}{l}1,806,439 \\
(26.5)\end{array}$ & $\begin{array}{l}13,096 \\
(33.8)\end{array}$ \\
\hline & $40-59$ & $\begin{array}{l}19,175,389 \\
(52.5)\end{array}$ & $\begin{array}{l}539,041 \\
(17.3)\end{array}$ & $\begin{array}{l}3,457,567 \\
(16.1)\end{array}$ & $\begin{array}{l}1,863,854 \\
(10.8)\end{array}$ & $\begin{array}{l}4,749,791 \\
(69.7)\end{array}$ & $\begin{array}{l}23,814 \\
(61.5)\end{array}$ \\
\hline & $60-79$ & $\begin{array}{l}8,930,724 \\
(24.4)\end{array}$ & $\begin{array}{l}945,316 \\
(30.4)\end{array}$ & $\begin{array}{l}12,914,363 \\
(60.3)\end{array}$ & $\begin{array}{l}11,322,374 \\
(65.4)\end{array}$ & $\begin{array}{l}166,351 \\
(2.4)\end{array}$ & $1,331(3.4)$ \\
\hline & $80+$ & $1,391,144(3.8)$ & $\begin{array}{l}1,026,239 \\
(33.0)\end{array}$ & $\begin{array}{l}2,319,469 \\
(10.8)\end{array}$ & $\begin{array}{l}2,086,627 \\
(12.0)\end{array}$ & $3,936(0.1)$ & $46(0.1)$ \\
\hline \multirow[t]{5}{*}{ Region } & North & $2,727,350(7.5)$ & $\begin{array}{l}394,193 \\
(12.7)\end{array}$ & $\begin{array}{l}1,348,827 \\
(6.3)\end{array}$ & $\begin{array}{l}1,123,269 \\
(6.5)\end{array}$ & $\begin{array}{l}465,931 \\
(6.8)\end{array}$ & 77 ( 0.2$)$ \\
\hline & $\begin{array}{l}\text { North } \\
\text { east }\end{array}$ & $\begin{array}{l}8,658,260 \\
(23.7)\end{array}$ & $\begin{array}{l}727,709 \\
(23.4)\end{array}$ & $\begin{array}{l}4,999,917 \\
(23.3)\end{array}$ & $\begin{array}{l}4,166,636 \\
(24.1)\end{array}$ & $\begin{array}{l}1,537,377 \\
(22.6)\end{array}$ & $285(0.7)$ \\
\hline & $\begin{array}{l}\text { South } \\
\text { east }\end{array}$ & $\begin{array}{l}16,228,228 \\
(44.4)\end{array}$ & $\begin{array}{l}1,317,335 \\
(42.3)\end{array}$ & $\begin{array}{l}10,008,792 \\
(46.7)\end{array}$ & $\begin{array}{l}7,671,701 \\
(44.3)\end{array}$ & $\begin{array}{l}2,983,870 \\
(43.8)\end{array}$ & $1,298(3.4)$ \\
\hline & South & $\begin{array}{l}6,096,419 \\
(16.7)\end{array}$ & $\begin{array}{l}415,226 \\
(13.3)\end{array}$ & $\begin{array}{l}3,479,160 \\
(16.2)\end{array}$ & $\begin{array}{l}3,019,037 \\
(17.4)\end{array}$ & $\begin{array}{l}1,220,697 \\
(17.9)\end{array}$ & $\begin{array}{l}36,901 \\
(95.2)\end{array}$ \\
\hline & $\begin{array}{l}\text { Cente } \\
\text { r-West }\end{array}$ & $2,847,979(7.8)$ & $\begin{array}{l}257,566 \\
(8.3)\end{array}$ & $\begin{array}{l}1,584,346 \\
(7.4)\end{array}$ & $\begin{array}{l}1,341,289 \\
(7.7)\end{array}$ & $\begin{array}{l}604,886 \\
(8.9)\end{array}$ & $184(0.5)$ \\
\hline Sex & $\mathrm{F}$ & $\begin{array}{l}20,054,648 \\
(54.9)\end{array}$ & $\begin{array}{l}1,926,966 \\
(61.9)\end{array}$ & $\begin{array}{l}12,632,426 \\
(59.0)\end{array}$ & $\begin{array}{l}10,293,819 \\
(59.4)\end{array}$ & $\begin{array}{l}3,901,877 \\
(57.3)\end{array}$ & $\begin{array}{l}26,180 \\
(67.6)\end{array}$ \\
\hline
\end{tabular}


medRxiv preprint doi: https://doi.org/10.1101/2021.09.10.21263084; this version posted September 15, 2021. The copyright holder for this preprint (which was not certified by peer review) is the author/funder, who has granted medRxiv a license to display the preprint in perpetuity.

It is made available under a CC-BY-NC-ND 4.0 International license .

\begin{tabular}{|c|c|c|c|c|c|c|c|}
\hline & $M$ & $\begin{array}{l}16,503,569 \\
(45.1)\end{array}$ & $\begin{array}{l}1,185,062 \\
(38.1)\end{array}$ & $\begin{array}{l}8,788,596 \\
(41.0)\end{array}$ & $\begin{array}{l}7,028,102 \\
(40.6)\end{array}$ & $\begin{array}{l}2,910,882 \\
(42.7)\end{array}$ & $\begin{array}{l}12,565 \\
(32.4)\end{array}$ \\
\hline Total & & $\mathrm{N}=36,558,236$ & $\begin{array}{l}\mathrm{N}= \\
3,112,029\end{array}$ & $\begin{array}{l}N= \\
21,421,043\end{array}$ & $\begin{array}{l}N= \\
17,321,933\end{array}$ & $\begin{array}{l}N= \\
6,812,761\end{array}$ & $\mathrm{~N}=38,745$ \\
\hline
\end{tabular}


medRxiv preprint doi: https://doi.org/10.1101/2021.09.10.21263084; this version posted September 15, 2021. The copyright holder for this preprint (which was not certified by peer review) is the author/funder, who has granted medRxiv a license to display the preprint in perpetuity.

It is made available under a CC-BY-NC-ND 4.0 International license.

Table 2: Severe COVID-19 cases among individuals in the cohort receiving ChAdOx1 nCov-19, CoronaVac, or BNT162b2 vaccines, by age group, region and sex, in Brazil from vaccination T0 to July 17, 2021. Values in percentages indicate the proportions of each stratum item by the total in the stratum/vaccine/regimen.

ChAdOx1 nCov-19

\begin{tabular}{|c|c|c|c|c|c|}
\hline & & $1+$ dose & & Full & \\
\hline & & $\begin{array}{l}\text { No observed outcome } \\
(\%)\end{array}$ & Case (\%) & $\begin{array}{l}\text { No observed } \\
\text { outcome (\%) }\end{array}$ & Case (\%) \\
\hline Age & $0-19$ & $285,017(0.8)$ & $44(0.1)$ & $15,158(0.5)$ & $2(0.1)$ \\
\hline & $20-39$ & $6,774,165$ (18.6) & $1,677$ ( 3.2$)$ & $586,198(18.9)$ & 75 ( 2.5) \\
\hline & $40-59$ & $19,164,198(52.5)$ & $10,778(20.7)$ & $538,912(17.3)$ & $129(4.3)$ \\
\hline & $60-79$ & $8,908,355(24.4)$ & $21,216(40.7)$ & $944,762(30.4)$ & $550(18.5)$ \\
\hline & $80+$ & $1,372,651$ ( 3.8) & $18,458(35.4)$ & $1,024,016(32.9)$ & $2,221(74.6)$ \\
\hline Region & North & $2,724,158(7.5)$ & 3,009 ( 5.8) & $393,917(12.7)$ & 275 ( 9.2) \\
\hline & Northeast & $8,647,390(23.7)$ & $10,288(19.7)$ & $726,961(23.4)$ & $747(25.1)$ \\
\hline & Southeast & $16,202,344(44.4)$ & $25,547(49.0)$ & $1,315,883(42.3)$ & $1,451(48.7)$ \\
\hline & South & $6,087,035(16.7)$ & $8,949(17.2)$ & 414,956 (13.3) & $269(9.0)$ \\
\hline & $\begin{array}{l}\text { Center- } \\
\text { West }\end{array}$ & $2,843,459$ ( 7.8) & $4,380(8.4)$ & $257,329$ ( 8.3$)$ & 235 ( 7.9$)$ \\
\hline Sex & $\mathrm{F}$ & $20,028,115(54.9)$ & 25,739 (49.3) & 1,925,327 (61.9) & $1,636(55.0)$ \\
\hline & M & $16,476,254(45.1)$ & $26,432(50.7)$ & $1,183,718(38.1)$ & $1,341(45.0)$ \\
\hline
\end{tabular}

CoronaVac

1+ dose

Full 
medRxiv preprint doi: https://doi.org/10.1101/2021.09.10.21263084; this version posted September 15, 2021. The copyright holder for this preprint (which was not certified by peer review) is the author/funder, who has granted medRxiv a license to display the preprint in perpetuity.

It is made available under a CC-BY-NC-ND 4.0 International license .

\begin{tabular}{|c|c|c|c|c|c|}
\hline & & $\begin{array}{l}\text { No observed outcome } \\
(\%)\end{array}$ & Case (\%) & $\begin{array}{l}\text { No observed } \\
\text { outcome (\%) }\end{array}$ & Case (\%) \\
\hline \multirow{5}{*}{$\begin{array}{l}\text { Age } \\
\text { group }\end{array}$} & $0-19$ & $86,471(0.4)$ & $36(0.0)$ & $53,944(0.3)$ & $15(0.0)$ \\
\hline & $20-39$ & $2,641,022(12.4)$ & $2,115(2.1)$ & $1,993,907(11.5)$ & $1,212(2.2)$ \\
\hline & $40-59$ & $3,452,956$ (16.2) & $4,611(4.6)$ & $1,861,313(10.8)$ & $2,541(4.6)$ \\
\hline & $60-79$ & $12,855,075(60.3)$ & $59,288(59.5)$ & $11,292,419$ (65.4) & 29,955 (53.7) \\
\hline & $80+$ & $2,285,836(10.7)$ & 33,633 (33.7) & $2,064,536(12.0)$ & $22,091(39.6)$ \\
\hline \multirow[t]{5}{*}{ Region } & North & $1,345,313(6.3)$ & $3,514(3.5)$ & $1,121,616(6.5)$ & $1,653(3.0)$ \\
\hline & Northeast & $4,982,980(23.4)$ & $16,937(17.0)$ & $4,158,085(24.1)$ & $8,551(15.3)$ \\
\hline & Southeast & $9,957,408(46.7)$ & $51,384(51.5)$ & $7,642,153(44.3)$ & $29,548(52.9)$ \\
\hline & South & $3,459,851(16.2)$ & $19,309(19.4)$ & $3,007,829(17.4)$ & $11,208(20.1)$ \\
\hline & $\begin{array}{l}\text { Center- } \\
\text { West }\end{array}$ & $1,575,808(7.4)$ & 8,538 ( 8.6) & $1,336,436(7.7)$ & $4,853(8.7)$ \\
\hline \multirow[t]{2}{*}{ Sex } & $\mathrm{F}$ & $12,582,596(59.0)$ & $49,830(50.0)$ & $10,265,647(59.5)$ & $28,172(50.5)$ \\
\hline & M & $8,738,752(41.0)$ & $49,844(50.0)$ & $7,000,464(40.5)$ & $27,638(49.5)$ \\
\hline \multicolumn{6}{|c|}{ BNT162b2 } \\
\hline \multirow{5}{*}{$\begin{array}{l}\text { Age } \\
\text { group }\end{array}$} & & $1+$ dose & & & \\
\hline & & $\begin{array}{l}\text { No observed outcome } \\
(\%)\end{array}$ & Case (\%) & & \\
\hline & $0-19$ & $86,235(1.3)$ & $5(0.5)$ & & \\
\hline & $20-39$ & $1,806,214(26.5)$ & $168(16.5)$ & & \\
\hline & $40-59$ & $4,748,872(69.7)$ & $724(71.3)$ & & \\
\hline
\end{tabular}


medRxiv preprint doi: https://doi.org/10.1101/2021.09.10.21263084; this version posted September 15, 2021. The copyright holder for this preprint (which was not certified by peer review) is the author/funder, who has granted medRxiv a license to display the preprint in perpetuity.

It is made available under a CC-BY-NC-ND 4.0 International license .

\begin{tabular}{|c|c|c|c|}
\hline & $60-79$ & $166,226$ ( 2.4$)$ & $113(11.1)$ \\
\hline & $80+$ & $3,924(0.1)$ & $6(0.6)$ \\
\hline \multirow[t]{5}{*}{ Region } & North & $465,867(6.8)$ & $64(6.3)$ \\
\hline & Northeast & $1,537,188(22.6)$ & $132(13.0)$ \\
\hline & Southeast & 2,983,234 (43.8) & $628(61.8)$ \\
\hline & South & $1,220,464(17.9)$ & $24(2.4)$ \\
\hline & $\begin{array}{l}\text { Center- } \\
\text { West }\end{array}$ & 604,718 ( 8.9) & 168 (16.5) \\
\hline \multirow[t]{2}{*}{ Sex } & $\mathrm{F}$ & $3,901,227$ (57.3) & $508(50.0)$ \\
\hline & $M$ & $2,910,242(42.7)$ & $508(50.0)$ \\
\hline
\end{tabular}


medRxiv preprint doi: https://doi.org/10.1101/2021.09.10.21263084; this version posted September 15, 2021. The copyright holder for this preprint (which was not certified by peer review) is the author/funder, who has granted medRxiv a license to display the preprint in perpetuity.

It is made available under a CC-BY-NC-ND 4.0 International license .

Table 3: Deaths due to severe COVID-19 among individuals in the cohort receiving ChAdOx1 nCov-19, CoronaVac, and BNT162b2 vaccines, by age group, region and sex, Brazil from vaccination T0 to July 17, 2021. Values in percentages indicate the proportions of each stratum item by the total in the stratum/vaccine/regimen.

\begin{tabular}{|c|c|c|c|c|c|}
\hline \multicolumn{6}{|c|}{ ChAdOx1 nCov-19 } \\
\hline & & \multicolumn{2}{|l|}{$1+$ dose } & \multicolumn{2}{|l|}{ Full } \\
\hline & & $\begin{array}{l}\text { No observed outcome } \\
(\%)\end{array}$ & Death (\%) & $\begin{array}{l}\text { No observed } \\
\text { outcome (\%) }\end{array}$ & Death (\%) \\
\hline \multirow[t]{5}{*}{ Age group } & $0-19$ & $285,058(0.8)$ & $6(0.0)$ & $15,160(0.5)$ & $0(0.0)$ \\
\hline & $20-39$ & $6,775,766(18.5)$ & $148(1.0)$ & $586,272(18.8)$ & $1(0.2)$ \\
\hline & $40-59$ & $19,173,636(52.5)$ & $1,734(11.4)$ & $539,029(17.3)$ & $12(1.9)$ \\
\hline & $60-79$ & $8,924,897(24.4)$ & $5,749(37.8)$ & $945,206(30.4)$ & $109(17.4)$ \\
\hline & $80+$ & $1,383,583$ ( 3.8$)$ & $7,555(49.7)$ & $1,025,734(33.0)$ & $505(80.5)$ \\
\hline \multirow[t]{5}{*}{ Region } & North & $2,726,401(7.5)$ & $949(6.2)$ & $394,129(12.7)$ & $64(10.2)$ \\
\hline & $\begin{array}{l}\text { Northe } \\
\text { ast }\end{array}$ & $8,654,903(23.7)$ & $3,286(21.6)$ & $727,530(23.4)$ & $179(28.5)$ \\
\hline & $\begin{array}{l}\text { Southe } \\
\text { ast }\end{array}$ & $16,220,897(44.4)$ & $7,331(48.3)$ & $1,317,053(42.3)$ & $282(45.0)$ \\
\hline & South & $6,093,995(16.7)$ & $2,424(16.0)$ & $415,180(13.3)$ & $46(7.3)$ \\
\hline & $\begin{array}{l}\text { Center- } \\
\text { West }\end{array}$ & $2,846,744(7.8)$ & $1,202(7.9)$ & 257,509 ( 8.3) & $56(8.9)$ \\
\hline \multirow[t]{2}{*}{ Sex } & $\mathrm{F}$ & $20,047,427(54.9)$ & $7,166(47.2)$ & $1,926,657(61.9)$ & 309 (49.3) \\
\hline & M & $16,495,494(45.1)$ & $8,026(52.8)$ & $1,184,743(38.1)$ & $318(50.7)$ \\
\hline \multicolumn{6}{|c|}{ CoronaVac } \\
\hline & & $1+$ dose & & Full & \\
\hline
\end{tabular}


medRxiv preprint doi: https://doi.org/10.1101/2021.09.10.21263084; this version posted September 15, 2021. The copyright holder for this preprint (which was not certified by peer review) is the author/funder, who has granted medRxiv a license to display the preprint in perpetuity.

It is made available under a CC-BY-NC-ND 4.0 International license .

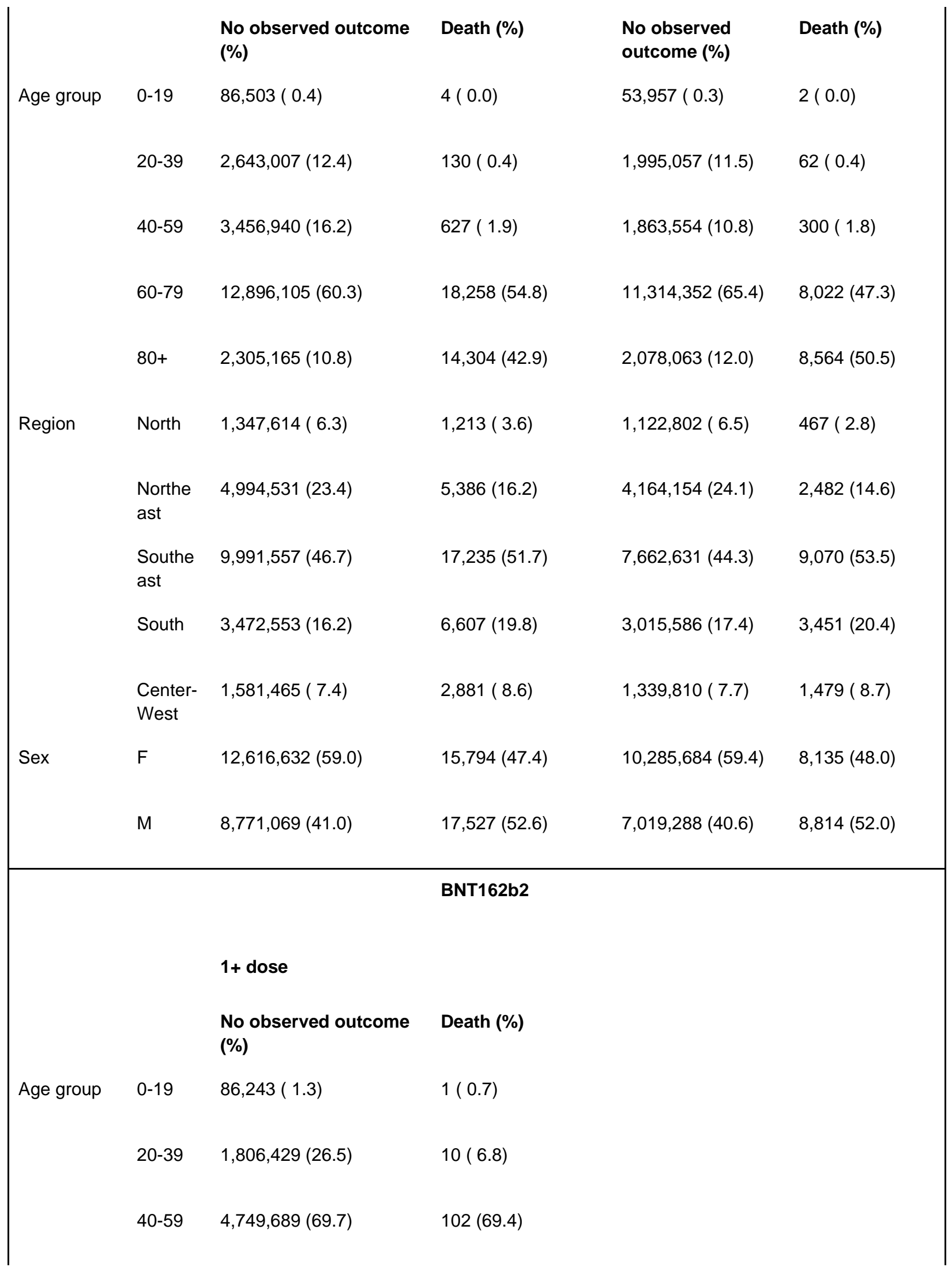


medRxiv preprint doi: https://doi.org/10.1101/2021.09.10.21263084; this version posted September 15, 2021. The copyright holder for this preprint (which was not certified by peer review) is the author/funder, who has granted medRxiv a license to display the preprint in perpetuity.

It is made available under a CC-BY-NC-ND 4.0 International license .

\begin{tabular}{|c|c|c|c|}
\hline & $60-79$ & 166,325 ( 2.4) & $26(17.7)$ \\
\hline & $80+$ & $3,928(0.1)$ & $8(5.4)$ \\
\hline \multirow[t]{5}{*}{ Region } & North & $465,925$ ( 6.8$)$ & $6(4.1)$ \\
\hline & $\begin{array}{l}\text { Northe } \\
\text { ast }\end{array}$ & 1,537,355 (22.6) & $22(15.0)$ \\
\hline & $\begin{array}{l}\text { Southe } \\
\text { ast }\end{array}$ & $2,983,805$ (43.8) & $65(44.2)$ \\
\hline & South & $1,220,664$ (17.9) & $33(22.4)$ \\
\hline & $\begin{array}{l}\text { Center- } \\
\text { West }\end{array}$ & 604,865 ( 8.9) & $21(14.3)$ \\
\hline \multirow[t]{2}{*}{ Sex } & $\mathrm{F}$ & $3,901,812(57.3)$ & $65(44.2)$ \\
\hline & M & $2,910,800(42.7)$ & $82(55.8)$ \\
\hline
\end{tabular}


medRxiv preprint doi: https://doi.org/10.1101/2021.09.10.21263084; this version posted September 15, 2021. The copyright holder for this preprint (which was not certified by peer review) is the author/funder, who has granted medRxiv a license to display the preprint in perpetuity.

It is made available under a CC-BY-NC-ND 4.0 International license .

Table 4: Vaccination effectiveness for individuals with at least first dose and fully immunized. The label "All vaccines" refers to the overall evaluation of the vaccination program.

\begin{tabular}{|c|c|c|c|c|c|}
\hline \multirow[b]{2}{*}{ Vaccine } & \multirow[b]{2}{*}{ Age group } & \multicolumn{2}{|l|}{ At least first dose } & \multicolumn{2}{|l|}{ Fully immunized } \\
\hline & & $\begin{array}{l}\begin{array}{l}\text { Severe } \\
\text { cases/deaths }\end{array} \\
\text { Est. }(95 \% \mathrm{Crl})\end{array}$ & $\begin{array}{l}\text { Deaths } \\
\text { Est. }(95 \% \mathrm{Crl})\end{array}$ & $\begin{array}{l}\begin{array}{l}\text { Severe } \\
\text { cases/deaths }\end{array} \\
\text { Est. }(95 \% \mathrm{Crl})\end{array}$ & $\begin{array}{l}\text { Deaths } \\
\text { Est. (95\% Crl) }\end{array}$ \\
\hline \multicolumn{6}{|c|}{ All vaccines } \\
\hline & $20-39$ & $54.9(53.4--56.3)$ & $72.2(68.8--75.3)$ & $61.7(59.6--63.8)$ & $83.7(79.5--87.5)$ \\
\hline & $40-59$ & $66.8(66.2--67.3)$ & $75.3(74.3--76.3)$ & $73.6(72.6--74.6)$ & $84.5(82.8--86.2)$ \\
\hline & $60-79$ & $55.1(54.7--55.4)$ & $64.4(63.9--64.9)$ & $61.0(60.5--61.5)$ & $71.8(71.2--72.4)$ \\
\hline & $80+$ & $23.9(22.9--24.9)$ & $35.3(34.0--36.5)$ & $35.9(34.9--36.9)$ & $51.4(50.2--52.6)$ \\
\hline \multicolumn{6}{|c|}{ CoronaVac } \\
\hline & $20-39$ & $48.5(46.2--50.7)$ & $72.5(67.5--77.1)$ & $58.4(56--60.7)$ & $81.5(76.6--85.8)$ \\
\hline & $40-59$ & $65.1(64.1--66.2)$ & $76.1(74.2--77.9)$ & $71.0(69.8--72.1)$ & $82.7(80.7--84.6)$ \\
\hline & $60-79$ & $50.2(49.7--50.6)$ & $58.9(58.2--59.5)$ & $60.4(59.9--60.9)$ & $71.2(70.6--71.9)$ \\
\hline & $80+$ & $21.8(20.7--23)$ & $33.2(31.7--34.6)$ & $29.6(28.5--30.8)$ & $45.0(43.6--46.4)$ \\
\hline \multicolumn{6}{|c|}{$\begin{array}{l}\text { ChAdOx1 nCov- } \\
19\end{array}$} \\
\hline & $20-39$ & $59.4(57.4--61.3)$ & $69.8(64.6--74.5)$ & $83.7(79.8--87.2)$ & $97.9(93.5--99.8)$ \\
\hline & $40-59$ & $65.0(64.3--65.6)$ & $72.7(71.4--74.0)$ & $90.4(88.7--92.0)$ & $95.6(92.7--97.8)$ \\
\hline & $60-79$ & $63.9(63.4--64.4)$ & $74.5(73.8--75.2)$ & $79.6(77.8--81.3)$ & $89.5(87.4--91.4)$ \\
\hline & $80+$ & $26.9(25.6--28.3)$ & $38.4(36.7--40.0)$ & $66.7(65.1--68.1)$ & $84.6(83.3--85.9)$ \\
\hline
\end{tabular}


medRxiv preprint doi: https://doi.org/10.1101/2021.09.10.21263084; this version posted September 15, 2021. The copyright holder for this preprint (which was not certified by peer review) is the author/funder, who has granted medRxiv a license to display the preprint in perpetuity.

It is made available under a CC-BY-NC-ND 4.0 International license .

BNT162b2*

20-39 $64.7(59.8--69.3) \quad 86.1(76.9--93.8) \quad$ -

40-59 $\quad 81.2(79.9--82.4) \quad 89.9(87.8--91.8) \quad-$

$60-79 \quad 81.6(78.3--84.6) \quad 89.6(85.1--93.2) \quad-$

$80+\quad 33.0(-10.7--65.1) \quad 8.6(-67.9--59.6)$

* Not evaluated in fully immunized 